\title{
Рекомендації щодо порядку застосування методичного підходу до воєнно-економічного обґрунтування вибору раціонального варіанту розвідувально-ударної системи або комплексу в програмах (планах)
}

\author{
Олег Семененко ${ }^{1}$ А; Артем Ремез ${ }^{2}$ в; Володимир Мусієнко 3 С; \\ Іван Мотрунич 4 D; Андрій Булгаков 5 A; Олег Тарасов 6 F \\ А Центральний науково-дослідний інститут 3бройних Сил України, пр-кт Повітрофлотський 28, м. Київ, 03049, Україна \\ в Національний університет оборони України імені Івана Черняховського, пр-кт Повітрофлотський 28, м. Київ, 03049, Україна \\ с Військовий інститут телекомунікацій та інформатизації імені Героїв Крут, вул. Московська, 45/1, м. Київ, 01011, Україна \\ D Генеральний штаб Збройних Сил України, пр-кт Повітрофлотський 6, м. Київ, 03168, Україна \\ F Кафедра військової підготовки Національного авіаційного університету, вул. Медова 1, м. Київ, 03048, Україна
}

Received: April 6, 2021 | Revised: April 27, 2021 | Accepted: April 30, 2021

DOI: $10.33445 / s d s .2021 .11 .2 .18$

\begin{abstract}
Анотація
Стан вітчизняної економіки та рівень впровадження сучасних технологій на підприємствах оборонно-промислового комплексу роблять проблематичним виконання у встановлені терміни всіх планів переозброєння Збройних Сил України. Тому найбільш прийнятним, як з воєнної, так і з економічної точки зору є підхід щодо ситуаційного інтегрування наявних сил і засобів у цільові системи в єдиному інформаційному просторі шляхом інтеграції засобів розвідки, управління та ураження. Тобто розвідувально-ударна система, побудована з множини підсистем об'єднаних інформаційними відносинами, які функціонують, як одне ціле, на основі єдиних принципів і правил, з погодженими основними вимогами до їх складових дозволить збільшити ефективність бойового застосування військ за рахунок синергетичного ефекту. Але інтегрування різних сил i засобів у цільові системи створює передумови щодо наявності декілька можливих варіантів цих систем, які мають різні оцінки ефективності їх застосування, вартісні показники їх створення, утримання та застосування, а також різні часові інтервали щодо їх створення та приведення у бойову готовність. Тому система показників і критеріїв оцінювання та порівняння різних варіантів розвідувально-ударно систем чи комплексів, а також методичні підходи щодо обґрунтування вибору раціонального варіанту цих систем чи комплексів повинні мати інтегральний критерій вибору пріоритетного варіанту в умовах обстановки, що складається на час оцінювання. Тому авторами в стапті запропоновано загальну структуру побудови методичного підходу до воєнно-економічного обґрунтування вибору раціонального варіанту розвідувально-ударної системи або комплексу 3 урахуванням воєнних, економічних та часових факторів, що вливають на їх створення, утримання та застосування, а також сформовано повну структурно-логічну схему цього підходу. У свою чергу запропонований методичний підхід дозволяє сформувати основні рекомендації щодо порядку його застосування в штабах, службах Збройних Силах України під час формування програм та планів розвитку озброєння та військової техніки Збройних Сил України та Збройних Сил України в цілому.
\end{abstract}

Ключові слова: показник, критерії, бойова готовність, розвідувально-ударна система.

\footnotetext{
${ }^{1}$ Corresponding author: д. військ. н., с.н.с., начальник відділу, е-mail: aosemenenko@ukr.net, ORCID: 0000-0001-6477-3414

2 ад'юнкт, e-mail: remez.art.86@gmail.com, ORCID: 0000-0003-4970-1097

3 e-mail: aosemenenko@ukr.net, ORCID: 0000-0002-4909-6045

${ }^{4}$ e-mail: aosemenenko@ukr.net, ORCID: 0000-0002-6463-7639

${ }^{5}$ e-mail: bulggakof@ukr.net, ORCID: 0000-0003-4139-6761

${ }^{6}$ кандидат військових наук, e-mail: tarasovo@ukr.net
} 


\section{Постановка проблеми}

Аналіз розвитку озброєння провідних країн світу та його застосування у сучасних воєнних конфліктах [1-12], свідчить про те, що сучасні вимоги до якості зразків озброєння та військової техніки (ОВТ) постійно зростають. Перед керівництвом держави та ЗС України, в умовах необхідності оновлення озброєння Збройних Сил (3С) України та недостатнього їх фінансування постійно постає завдання обґрунтування вибору зразків озброєння на перспективу [1, 5]. Обрані в програмах розвитку ОВТ та $3 \mathrm{C}$ України перспективні зразки озброєння повинні задовольняти вимоги щодо вирішення завдань, які постають перед 3С, i бути економічно досяжними (реальними). Сьогодні в складних умовах розвитку 3С України, більшість перспективних зразків озброєння визначаються за принципом аналогії чи мінімально необхідної потреби без урахування економічних можливостей держави $[2,5,7]$. У сучасних умовах розвитку 3С України ці задачі повинні вирішуватися тільки на основі критеріїв воєнно-економічної ефективності. У загальному вигляді, постановка вирішення задач вибору раціонального перспективного зразка озброєння може бути двох видів: перший мінімізація витрат за фіксованого рівня ефективності зразка озброєння; другий: максимізація ефективності за фіксованого ресурсного показника. У більшості провідних країн світу перша постановка вважається найбільш прийнятною $[3,4]$, бо кількість та якість ОВТ країни $€$ похідною від рівня ії безпеки, який визначається наявністю воєнних загроз. Формування критерію воєнно-економічної ефективності згідно із задачею першої постановки зводиться до визначення ресурсного (економічного) показника. За визначенням, ресурсний показник воєнно-економічної ефективності становить кількісну характеристику ресурсів, які витрачаються для досягнення потрібного рівня ефективності зразка озброєння. Тому вирішення задачі вибору раціонального варіанту розвідувально-ударної системи (РУС) або комплексу (РУК), також повинно враховувати показники не тільки цільової їх ефективності, тобто ефективності їх бойового застосування, а й показники воєнноекономічної доцільності їх створення та розвитку, бо завищені вимоги до варіанту РУК (РУС) створюють ризики щодо не досягнення кінцевого запланованого результату, як за строками виконання заходів щодо їx створення та приведення у бойову готовність, так i за економічними можливостями держави як на етапах створення цих систем, так і під час їх утримання та розвитку. Тому система показників і критеріїв оцінювання та порівняння різних варіантів розвідувальноударно комплексів та систем повинна враховувати оцінки їх бойової ефективності застосування кожного із варіантів, достатності економічних ресурсів держави щодо створення та утримання розроблених систем, а також своєчасності їх створення та приведення у бойову готовність, тобто вибір повинен проводитися за складовим критерієм “бойова ефективність - вартість час".

\section{Аналіз останніх досліджень та публікацій}

Сьогодні у багатьох країнах світу здійснюється перегляд теорії побудови i практики застосування, як нових комплексів, так і існуючих зразків озброєння 3 урахуванням організації та ведення бойових дій у єдиному інформаційному та кібернетичному просторі [1-12]. Вирішується питання, як досягти скорочення часу повного циклу бойового застосування комплексу озброєння для випередження противника у досягненні мети [7]. Разом з тим, як відмічається в [5], стан вітчизняної економіки та рівень впровадження сучасних технологій на підприємствах ОПК роблять проблематичним виконання у встановлені терміни всіх планів переозброєння ЗС України. Найбільш прийнятним, як з воєнної так і економічної точки зору $є$ підхід щодо 
ситуаційного об'єднання наявних сил і засобів у цільові системи в єдиному інформаційному просторі шляхом інтеграції існуючих зразків ОВТ з тими, які створюються з урахуванням сил і засобів систем зв'язку і управління, геоінформаційних та інших інформаційних систем. Комбінація сил і засобів у єдину розвідувально-ударну систему передбачає створення декілька варіантів (наборів) існуючих та перспективних сил і засобів, оцінювання яких буде характеризуватися показниками ефективності їх застосування з урахуванням ресурсних i часових обмежень щодо їх створення та приведення у бойову готовність. Тому сьогодні $\epsilon$ актуальним питання визначення методичного підходу до вибору раціонального варіанту розвідувальноударної системи або комплексу для ЗС України із множини запропонованих на основі оцінок ефективності їх бойового застосування та із урахуванням оцінок впливу економічних, часових та інших факторів, а також розроблення практичних рекомендацій щодо порядку застосування цього підходу в штабах, службах ЗС України.

\section{Постановка завдання}

Метою статті $\epsilon$ формування загальної структури та повної структурно-логічної схеми методичного підходу до воєнноекономічного обґрунтування вибору раціонального варіанту РУС (РУК), а також розроблення практичних рекомендацій щодо порядку застосування цього підходу в штабах, службах Збройних Сил України під час планування розвитку ОВТ зС України.

\section{Виклад основного матеріалу}

Загальна структура методичного підходу до воєнно-економічного обґрунтування вибору раціонального (пріоритетного варіанту в умовах обстановки, що складається) варіанту розвідувально-ударної системи або комплексу для ЗС України наведено на мал. 1.

Необхідність скорочення часу і підвищення якості виконання завдань розвідки і подальшого вогневого ураження об'єктів противника зумовлює необхідність створення нових розвідувально-ударних систем (РУС) та комплексів (РУК), під якими будемо розуміти визначену кількість зразків озброєння і військової техніки, що об'єднані в єдину систему (комплекс) за напрямами розвідка, управління, ураження з метою виконання визначеного бойового завдання.

В умовах обмеженого фінансового ресурсу та обмежень щодо здатності обороно промислового комплексу (ОПК) України до повного циклу розроблення складних зразків озброєння та військової техніки (кораблі, літаки тощо) створення нових РУС (РУК) доцільно виконувати в результаті покрокового (в загальному випадку ітераційного, еволюційного) $[1,2,7,9]$ проведення наступних основних робіт: аналіз загроз та визначення основних завдань ЗС України у сфері ймовірного збройного протистояння, а також формування багаторівневого переліку критично важливих об'єктів противника, які плануються до ураження; визначення раціонального складу сил і засобів РУС (РУК) для різних варіантів збройних зіткнень, які здатні адекватно виконати завдання щодо протидії противнику на відповідних операційних напрямках і оперативно впливати на об'єкти противника; розроблення та вдосконалення форм і способів ведення бойових дій у складі об'єднаних сил (ОС); удосконалення технологій вогневого (функціонального, радіоелектронного) ураження і забезпечення бойових дій; оптимізації складу сил і засобів елементів РУс (РУК), а також реструктуризація заходів бойової підготовки тощо [3-10]. 
ЕТАП 1 - Формування варіантів можливих РУК (РУС) ЗС України залежно від можливих сценаріїв застосування ЗС України в операціях на $\mathrm{t}$-й рік їх розвитку

\begin{tabular}{|c|c|c|c|}
\hline $\begin{array}{c}\text { Блок № } 1 \text { - } \\
\text { Формування варіантів } \\
\text { можливих РУК (РУС) ЗС } \\
\text { України в залежності від } \\
\text { можливих сценаріїв } \\
\text { застосування 3С України в } \\
\text { операціях на } t \text {-й рік їх } \\
\text { розвитку }\end{array}$ & $\begin{array}{c}\text { Блок № } 2 \text { - } \\
\text { Формування } \\
\text { вербально-числових } \\
\text { шкал порівняльного } \\
\text { оцінювання } \\
\text { пріоритетності } \\
\text { варіантів на } t \text {-й рік }\end{array}$ & $\begin{array}{c}\text { Блок № } 3 \text { - } \\
\text { Формування груп } \\
\text { компетентних } \\
\text { експертів для } \\
\text { проведення процедур } \\
\text { оцінювання та } \\
\text { порівняння різних } \\
\text { варіантів РУК (РУС) }\end{array}$ & $\begin{array}{c}\text { Блок № } 4 \text { - } \\
\text { Попередній розрахунок } \\
\text { коефіцієнтів } \\
\text { пріоритетності варіантів } \\
\text { РУк (РУС) на t-й рік без } \\
\text { прив'язування до бойової } \\
\text { обстановки }\end{array}$ \\
\hline
\end{tabular}

ЕТАП 2 - Оцінювання ефективності бойового застосування варіантів РУК (РУС) за різних обсягів виконання бойових завдань

Блок № 1 -

Оцінювання експертами варіантів можливих РУК (РУС)

ЗС України (Nj) за різних обсягів виконання бойових завдань (Vi) за складовими (розвідка, управління, ураження)

Блок № 2 -

Формування математичної моделі щодо вирішення задачі обгрунтування вибору раціонального варіанту РУК (РУС) ЗС України

ЕТАП 3 - Уточнення математичної моделі вибору раціонального варіанту РУК (РУС) з урахуванням критеріїв економічно достатності та своєчасності розроблення)

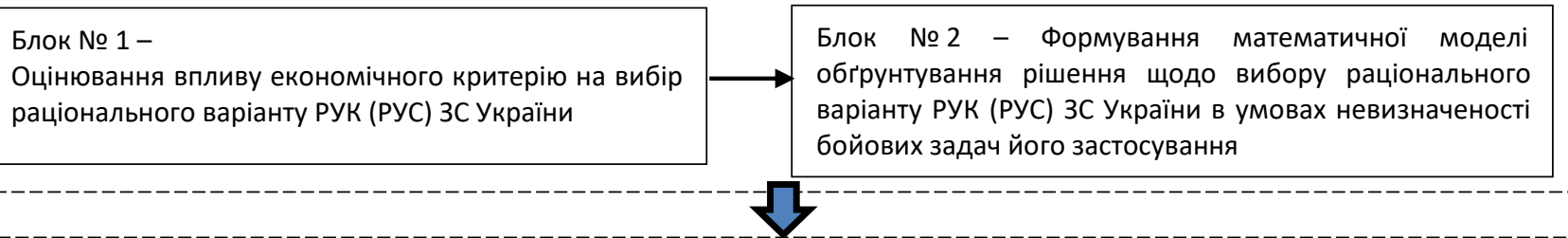

ЕТАП 4 - Вибір та обгрунтування раціонального варіанту РУК (РУС) ЗС України на t-й рік з урахуванням воєнного, економічного та часового критерію

\section{Блок № 1 -}

Аналіз платіжної матриці станів завдання можливими варіантами РУК (РУС) ЗС України на $t$-й рік ефективності виконання бойового

$\rightarrow$\begin{tabular}{l|l|}
$\begin{array}{l}\text { Блок № 2- } \\
\text { Пошуку сідлової } \\
\begin{array}{l}\text { Tочки в матриці } \\
\text { станів }\end{array}\end{array} \rightarrow \begin{array}{l}\text { Блок № 3- } \\
\text { Вибору } \\
\text { домінуючих } \\
\text { стратегій }\end{array}$ \\
\hline
\end{tabular}

Блок № 4 Зведення матриці станів до матриці $2 \times 2$ за домінуючими стратегіями

\section{$\downarrow$}

Блок № 8 - Визначення оптимальної обгрунтованого варіанту РУК (РУC) 3С

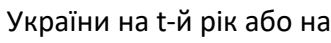
період $\mathrm{T}$

\begin{tabular}{|c|}
\hline $\begin{array}{l}\text { Блок № 7- Визначення ціни } \\
\text { гри } \\
\text { обгрунтованості } \\
\text { того чи іншогоно варіанту РУк } \\
\text { (РУС) відповідно до матриці } \\
\text { станів }\end{array}$ \\
\hline
\end{tabular}

Блок № 6 - Вибору оптимальної стратегії щодо варіанту РУк (РУС)зС України на tй рік
Блок № 5 -

Розрахунок ймовірностей виникнення домінуючих стратегій для $A(P 1, P 2)$ та $\mathrm{B}(\mathrm{Q} 1, \mathrm{Q} 2)$ на t-й рік

ЕТАП 5 - Розроблення рекомендацій щодо вибору раціонально варіанту розвідувально-ударної системи ЗС України

Рекомендації щодо розвитку визначеного пріоритетного варіанту РУК (РУК) та приведення його у готовність до застосування за призначенням
Рекомендації щодо порядку застосування визначеного раціонального варіанту РУК (РУС) у Операціях Об'єднаннях Сил (обмеження, потреби щодо забезпечення та особливості розгортання)

Малюнок 1 - Загальна структура методичного підходу до воєнно-економічного обґрунтування вибору раціонального варіанту розвідувально-ударної системи або комплексу для Збройних Сил України 


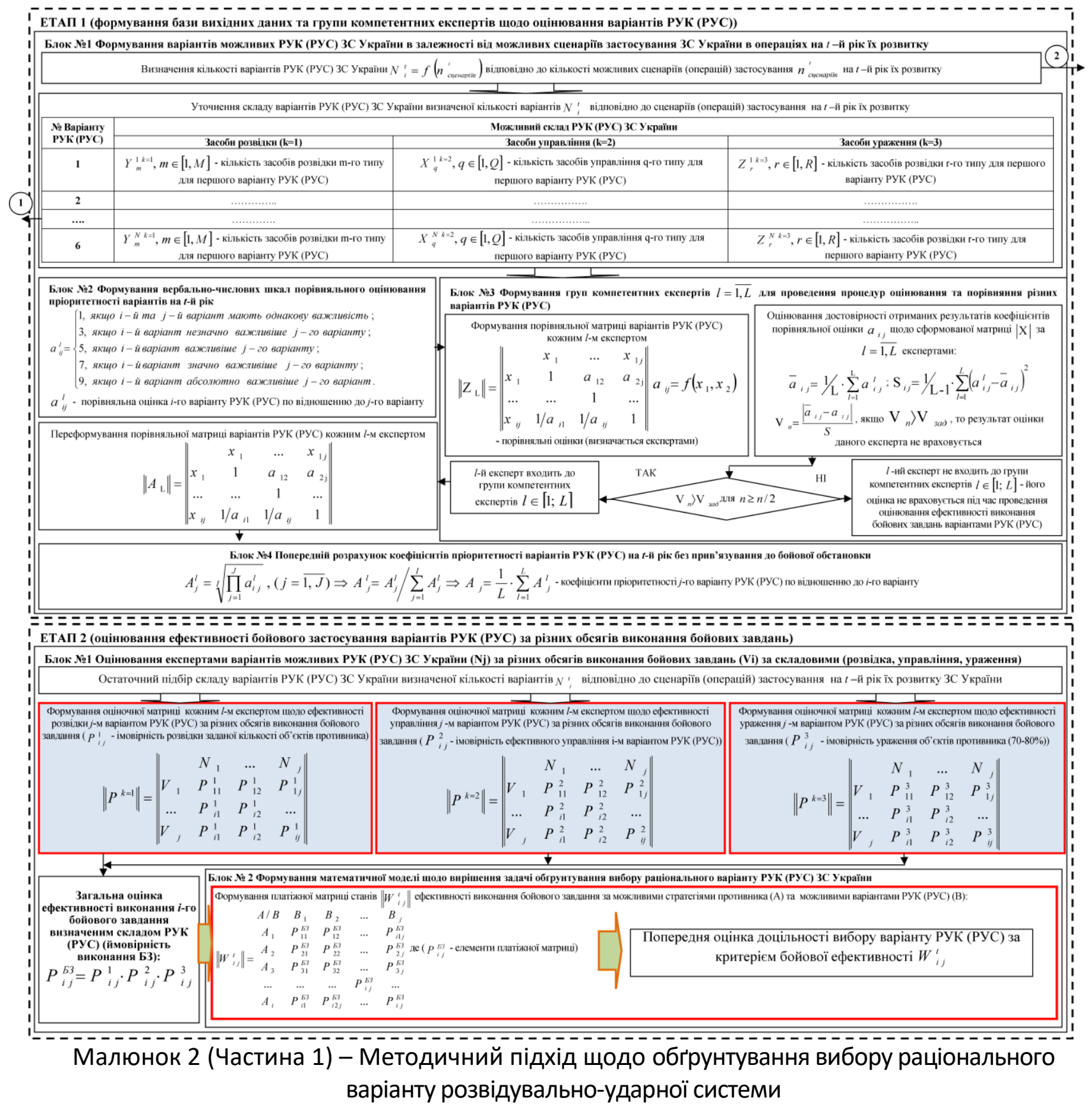

Повну структурно-логічну схему методичного підходу до вибору раціонального варіанту розвідувально-ударної системи в операціях об'єднаних сил ЗС України представлено на мал. 2 (Частина 1 та 2). Методичний підхід складається 3 п'яти взаємопов'язаних етапів. Кожен етап передбачає застосування окремих математичних методів або їх комбінацій за кожним кроком окремо взятого етапу.
Основними методами досліджень під час воєнно-економічного обґрунтування раціонального варіанту РУС (РУК) ЗС України $є$ : методи експертного опитування, які використовуються для збору та оцінювання інформації; методи математичної статистики і теорії ігор для оцінювання різних варіантів РУС (РУК) та прийнятя рішень в умовах невизначеності обстановки; а також методи воєнно-економічного аналізу та елементи теорії ймовірностей. 


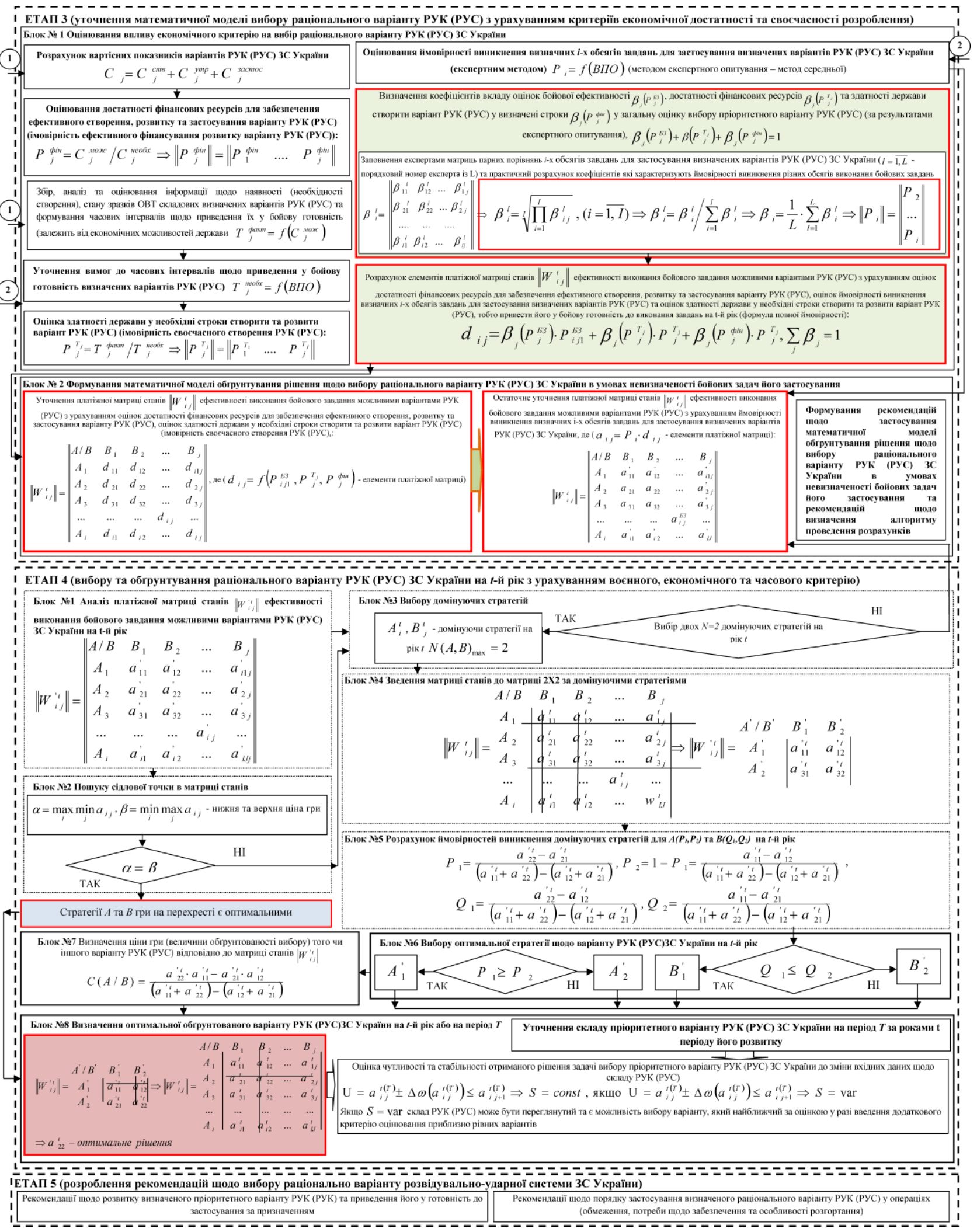

\section{Малюнок 2 (Частина 2) - Методика обґрунтування вибору раціонального варіанту розвідувально-ударної системи}

На основі розроблених загальної структури структурно-логічної схеми можна сформувати методичного підходу та повної його ряд рекомендацій щодо загального порядку 
застосування розробленого підходу в штабах, службах ЗС України під час формування програм та планів розвитку ОВТ ЗС України та ЗС України в цілому.

До основних рекомендацій першого етапу можна віднести те, що на цьому етапів спеціалістами оборонного планування разом із науковцями та дослідниками формуються можливі варіанти РУК (РУС) ЗС України залежно від визначених сценаріїв застосування 3С України в операціях на час або період їх розвитку. Сценарії застосування визначаються спеціалістами планування застосування ЗС України, а саме спеціалістами оперативного управлінням Генерального штабу (ГШ) ЗС України. Цей етап $\epsilon$ достатньо об'ємним кроком проведення розрахунків, тому що для формування вихідних даних щодо вибору та обґрунтування складу варіантів РУК (РУС) необхідно опрацювати значний об'єм інформації щодо показників бойової ефективності складу РУК (РУС) за напрямами: засоби розвідки; засоби управління; засоби ураження. Також на цьому етапі необхідно визначити (спрогнозувати) можливі сценарії застосування РУК (РУС). Далі для проведення вибору раціонального варіанту РУК (РУС) за отриманим масивом інформації, необхідно залучити експертів до групи, яка буде оцінювати, як варіанти РУК (РУС), так і ймовірні сценарії їх застосування. Експерти повинні бути спеціалістами в питаннях створення, утримання та застосування систем розвідки, управління та ураження. Далі із зібраної групи необхідно сформувати групу компетентних експертів для проведення оцінювання варіантів РУК (РУС). Визначена процедура необхідна для підвищення узгодженості думки експертів та зниження похибки оцінювання.

До основних рекомендацій другого етапу можна віднести те, що на цьому етапі спеціалісти різних видів ЗС України, а також група визначених компетентних експертів повинна провести оцінювання ефективності бойового застосування варіантів РУК (РУС) за різних обсягів виконання бойових завдань. Основними кроками цього етапу $\epsilon$ оцінювання за допомогою експертної групи можливих варіантів РУК (РУС) 3 подальшим формуванням загальної оцінки ефективності виконання кожного можливого бойового завдання визначеним складом РУК (РУС). На цьому етапі проведення розрахунків рекомендовано здійснити ретельний відбір групи експертів, експерти повинні бути сформовані за напрямами розвідка, управління та застосування РУК (РУС) під час ведення бойових дій різних масштабів, а також окремою часткою групи експертів повинна бути група спеціалістів оборонного планування, які будуть здійснювати воєнноекономічну оцінку доцільності запропонованих варіантів з метою прийняття рішень щодо вибору найбільш раціонального варіанту в умовах існуючих ресурсних обмежень. Рекомендовано основним показником оцінювання ефективності виконання різних обсягів бойових завдань обраним варіантом РУК (РУС) обрати показник імовірності виконання цих завдань. Головним результатом розрахунків цього етапу повинні бути попередні оцінки пріоритетності вибору варіанту РУК (РУС) із можливої їх множини.

До основних рекомендацій третього етапу можна віднести необхідність залучення науковців до проведення досліджень та розрахунків щодо уточнення математичної моделі вибору раціонального варіанту РУк (РУС) $з$ урахуванням критеріїв економічної достатності та своєчасності розроблення i приведення у бойову готовність кожного варіанту РУК (РУС), які повинні бути сформовані керівниками відповідних структурних підрозділів ГШ ЗС України, що відповідають за виконання завдань та заходів програм та планів розвитку ОВТ ЗС України та ЗС України в цілому. Основними кроками цього етапу повинні бути:

розрахунки щодо вартісних показників створення, Утримання та застосування можливих варіантів РУК (РУС) з подальшим 
розрахунком показника достатності економічних можливостей держави щодо ефективного забезпечення створення та розвитку кожного можливого варіанту РУК (PУC);

оцінювання здатності держави у необхідні строки створити та привести у бойову готовність різні варіанти РУК (РУС);

оцінювання ймовірності виникнення різних сценаріїв застосування РУК (РУС) в залежності від ймовірних обсягів завдань, які нам визначає ймовірний противник.

Сьогодні у запропонованому методичному підході рекомендується у якості математичної моделі обгрунтування рішень щодо вибору раціонального варіанту РУС (РУК) ЗС України в умовах невизначеності середовища виникнення бойових завдань для РУС (РУК) обрати матричну гру, основними елементами якої $\epsilon$ оцінки ефективності виконання бойових завдань із урахуванням впливів різних факторів (достатності забезпечення, своєчасності розроблення, ймовірності виникнення сценарію застосування варіанту РУС тощо). Тобто елементи платіжних матриць являють собою багатокритеріальну оцінку, де оцінки кожного критерію збираються у загальний (інтегральний) критерій за допомогою вагових коефіцієнтів їх вкладу у загальну оцінку пріоритетності варіанту РУК (РУС). Рішення математичної моделі необхідно здійснювати із застосуванням математичного апарату теорії ігор.

До основних рекомендацій четвертого етапу воєнно-економічного обґрунтування вибору раціонального варіанту РУС (РУК) можна віднести необхідність формування загальних критеріїв обґрунтування вибору доцільного варіанту РУК (РУС) ЗС України на час або період планування з урахуванням впливів воєнного, економічного та часового фактору, оцінка величини впливу повинна проводитися експертною групою на основі статистичної інформації щодо динаміки цих факторів не менше чим за середньорічний період.
На четвертому етапі рекомендовано спеціально сформованій групі науковців та дослідників за сформованими математичними матричними моделями провести рішення матричних ігор з метою визначення оптимальної стратегії щодо вибору раціонального варіанту РУК (РУС). У разі наявності чітко домінуючої стратегії рішення приймається у чистих стратегіях. У разі наявності декілька домінуючих стратегій матрична модель шляхом виключення невигідних стратегій зводиться до матриці розміром два на два 3 подальшим визначенням оптимальної стратегії щодо варіанту РУК (РУС) в умовах, що складаються на час або період оцінювання. Кінцевим результатом цього етапу повинні бути оцінки пріоритетності РУК (РУС) за різних умов їх застосування. За максимальною оцінкою пріоритетності обирається раціональний варіант РУК (РУС), який є найбільш доцільним в умовах обстановки, що склалася на час оцінювання. Отриманні рішення рекомендовано доповісти керівництву ЗС України з метою прийняття рішень щодо удосконалення існуючих або розроблення нових елементів обраного варіанту РУС (РУК) та внесення відповідних змін до програм та планів розвитку ОВТ ЗС України та ЗС України в цілому.

Також на цьому етапі можна рекомендувати проведення додаткової процедури щодо аналізу чутливості та стабільності прийнятих рішень до зміни вхідних даних розрахунків. Рекомендовано оцінювання чутливості та стабільності отриманого рішення щодо обраного варіанту РУК (РУС) провести на основі розрахунків абсолютної та відносної похибки вимірювання.

П’ятий етап повинен бути етапом розроблення та прийняття рішень, на основі яких будуть формуватися рекомендації щодо вибору раціонально варіанту розвідувальноударного комплексу чи системи ЗС України, за напрямами:

щодо воєнно-економічного обґрунтування 
раціонального варіанту РУК (РУС) 3 урахуванням загроз, що визначаються на перспективу, та вартісних показників створення, утримання та застосування обраного варіанту;

щодо перспектив подальшого розвитку визначеного пріоритетного варіанту РУК (РУК) та приведення його у готовність до застосування за призначенням;

щодо порядку застосування визначеного раціонального варіанту РУК (РУС) у Операціях Об'єднаннях Сил (обмеження, потреби щодо забезпечення та особливості розгортання).

Кінцевим результатом розрахунків відповідно до запропонованого методичного підходу $\epsilon$ формування рекомендацій та пропозицій щодо вимог до обраного варіанту РУК (РУС) 3С України та обґрунтованих показників потреб у фінансових ресурсах за роками розвитку обраного варіанту РУК (РУС) 3С України, які формуються на основі результатів практичних розрахунків. Застосування методичного підходу передбачається в системі оборонного планування на рівні ГШ 3С України та видів 3С України:

під час формування програм та планів розвитку ОВТ ЗС України та 3С України в цілому;

під час формування прогнозованих показників обсягів оборонних витрат за роками програм розвитку ОВТ ЗС України та ЗС України в цілому;

під час формування замислу щодо застосування 3С України та планування операцій Об'єднаних сил.

Основними елементами новизни запропонованого методичного підходу $€$ те, що на відміну від відомих підходів, уперше:

розроблено спосіб формування груп компетентних експертів для проведення процедур оцінювання та порівняння різних варіантів РУК (РУС) за критерієм "ефективність - вартість - час";

запропоновано методичний підхід до оцінювання ефективності РУК (РУС) операціях із урахуванням критеріїв економічної достатності та своєчасності створення;

розроблено спосіб обґрунтування вибору раціонального варіанту РУК (РУС) в операціях Об'єднаних Сил 3С України в умовах невизначеності бойової обстановки на основі математичного апарату теорії ігор;

розроблено рекомендації щодо воєнноекономічного обґрунтування вибору раціонального варіанту РУС (РУК) для ЗС України 3 урахуванням особливостей функціонування системи оборонного планування в Україні.

\section{Висновки}

Таким чином, запропонований методичний підхід до воєнно-економічного обґрунтування вибору раціонального варіанту розвідувально-ударної системи для Збройних Сил України є підґрунтям для розроблення практичних дієвих рекомендацій щодо вибору раціонального варіанту РУК (РУС) для ЗС України, яка на відміну від існуючих під час вибору пріоритетного варіанту РУК (РУС) дозволить урахувати показники бойової ефективності застосування варіантів РУК (РУС), достатність економічних можливостей держави щодо створення, утримання та застосування визначеного варіанту РУК (РУС), своєчасність створення та приведення обраного варіанту у бойову готовність, а також особливості обстановки прийняття рішень в умовах невизначеності кількості сил і засобів противника.

Запропоновані у статті рекомендації щодо застосування методичного підходу до воєнно-економічного обґрунтування вибору раціонального варіанту РУС (РУК) ЗС України дозволять підвищити обґрунтованість рішень щодо застосування розвідувально-ударних комплексів та систем 3С України, а також достовірність результатів щодо оцінювання ефективності їх застосування та обґрунтованість необхідних матеріальних та 
фінансових ресурсів для створення, утримання та застосування цих комплексів та систем. Такі результати сприятимуть підвищенню рівня розвитку ЗС України в цілому та ефективності використання державних коштів в умовах обмежень фінансових ресурсів на їх розвиток.

\section{Список використаних джерел}

1. Комплекс вооружения.

http://knowledge.su/k/kompleksvooruzheniya.

2. Даник Ю. Г. та інш. Моніторинг об'єктів в умовах апріорної невизначеності джерел інформації. Теорія та практика / авторський колектив Ю. А. Бобало, Ю. Г. Даник, Л. О. Комаровіа, О. О. Лукянов, В. М. Максимович, О. О. Писарчук, В. В. Ріппенбейн, Р. Т. Смук, В. С. Стогній, Ю. Б. Сторонський, Б. М. Стрихалюк. - Дрогобич - Львів: Коло, 2014. 252 с.

3. Розвідувально-ударні, розвідувальновогневі комплекси (принципи побудови в умовах реалізації концепції мережецентричних війн, оцінка ефективності бойового застосування) : монографія / за заг. ред. В. М. Телелима / В. М. Тарасов, Р. І. Тимошенко, О. М. Загорка. - К. : НУОУ ім. Івана Черняховського, 2015. - 184 с.

4. Загорка О. М. До питання застосування розвідувально-ударних і розвідувальновогневих комплексів у мережецентричній війні / О. М. Загорка, В. О. Колесников, В. В. Коваль, І. О. Загорка // Наука і техніка Повітряних Сил Збройних Сил України. 2012. - № 3. - C. 8-13. URL: http://nbuv.gov.ua/UJRN/Nitps_2012_3_5.

5. Хомчак Р.Б., Семненко О.М., Бокій В.Г., Зварич А.О., Ремез А.В. Теоретичні аспекти прогнозування результатів розвитку Збройних Сил України з урахуванням оцінок достатності економічних можливостей держави // 3б. наук. пр. ЦНДІ 3С України. Київ. 2020. № 2 (93). С. 6-24.

6. Разведывательно-ударные комплексы и разведывательные системы иностранных армий

URL:

http://studbooks.net/1194609/bzhd/razved yvatelno_udarnye_kompleksy_razvedyvatel nye_sistemy_inostranny $h$ _armiy.
7. Семененко, О., Салкуцан, С., Романченко, О., Марко, Є., Добровольська, Л., \& Ремез, А. (2020). Основні методологічні аспекти оцінювання взаємозв'язку оборонного та економічного потенціалу держави у рамках формування вимог до ії ефективного розвитку. Journal of Scientific Papers "Social Development and Security", 10(6), 161-177. DOI: 10.33445/sds.2020.10.6.15

8. Космос и характер современных военных действий. URL: http://kiksssr.ru/Main_Oko.htm.

9. Semenenko O., Vodchyts O., Bulhakov A., Remez A., Remez V. (2021) Methodological approach to justification of decisions on update of samples of weapons and military equipment on the basis of the criteria of economy of economy of performance by them of tasks on purpose // Sciences of Europe, (Praha, Czech Republic), vol 3, № 63, pp. 49-55.

10. Телелим В. М., Музиченко Д. П., Пунда Ю. В. Планування сил для виконання бойових завдань у «гібридній війні» // Наука i оборона №3. 2014. С.30-35.

11. Саяпин О.В., Тиханычев О.В., Чернов Н.А. Создание межвидовой разведывательнопоражающей системы как основы повышения эффективности огневого поражения // Военная мысль. - 2017. №6. - С. 32-37.

12. Семененко О. М., Ремез А. В., Романченко О. А., Бондаренко О. $€$. Загальна структурно-логічна схема та зміст методики воєнно-економічного обгрунтування вибору раціонального варіанту розвідувально-ударної системи для Збройних Сил України / 3б. наук. пр. Центрального науково-дослідного інституту Збройних Сил України. Київ: ЦНДІ 
3С України, 2020. №4 (95). С. 36-45.

13. The Implementation of Network - Centric Warfare - [Електронний ресурс] URL: http://www.iwar.org.uk/ rma /resources/ ncw/ implementation-of-NCW.pdf.

\title{
Рекомендации по применению методического подхода к военно-экономическому обоснованию выбора
}

\section{рационального варианта разведывательно-ударной системы или комплекса в программах (планах)}

\author{
Олег Семененко ${ }^{1 \text { А; } \text { Артем Ремез }}{ }^{2}$ в; Владимир Мусиенко 3 С;

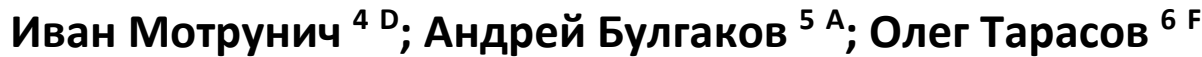 \\ ${ }^{1}$ Corresponding author: д.в.н., с.н.с., начальник отдела, e-mail: aosemenenko@ukr.net, ORCID: 0000-0001-6477-3414 \\ 2 адъюнкт, e-mail: remez.art.86@gmail.com, ORCID: 0000-0003-4970-1097 \\ ${ }^{3}$ e-mail: aosemenenko@ukr.net, ORCID: 0000-0002-4909-6045 \\ 4 e-mail: aosemenenko@ukr.net, ORCID: 0000-0002-6463-7639 \\ 5 e-mail: bulggakof@ukr.net, ORCID: 0000-0003-4139-6761 \\ ${ }^{6}$ кандидат военных наук, e-mail: tarasovo@ukr.net \\ А Центральный научно-исследовательский институт Вооруженных Сил Украины, пр-кт Воздухофлотский, 28, г. Киев, 03049, Украина

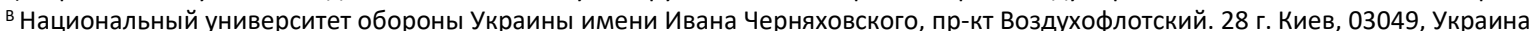 \\ с Военный институт телекоммуникаций и информатизации имени Героев Крут, ул. Московская, 45/1, г. Киев, 01011, Украина \\ D Генеральный штаб Вооруженных Сил Украины, пр-кт Воздухофлотский 6, г. Киев, 03168, Украина \\ F Кафедра военной подготовки Национального авиационного университета, ул. Медовая, 1, г. Киев, 03048, Украина
}

\begin{abstract}
Аннотация
Состояние отечественной экономики и уровень внедрения современных технологий на предприятиях оборонно-промышленного комплекса делают проблематичным выполнение в установленные сроки всех планов перевооружения Вооруженных Сил Украины. Поэтому наиболее приемлемым, как с военной, так и с экономической точки зрения является подход ситуационного интегрирования имеющихся сил и средств в целевые системы в едином информационном пространстве путем интеграции средств разведки, управления и поражения. Разведывательно-ударная система, построенная из множества подсистем объединенных информационными отношениями, которые функционируют, как одно целое, на основе единых принципов и правил, с согласованными основными требованиями к их составляющим, что позволит повысить эффективность боевого применения войск за счет синергетического эффекта. Сегодня интегрирование различных сил и средств в целевые системы создает предпосылки к наличию несколько возможных вариантов этих систем, имеющих различные оценки эффективности их применения, стоимостные показатели их создания, содержания и применения, а также различные временные интервалы по их приведению в боевую готовность. Поэтому система показателей и критериев оценки и сравнения различных вариантов разведывательно-ударных систем или комплексов, а также существующие подходы к обоснованию выбора рационального варианта этих систем или комплексов должны иметь интегральный критерий выбора приоритетного варианта в условиях складывающейся обстановки. Поэтому авторами в статье предложено общую структуру построения методического подхода до военно-экономического обоснования выбора рационального варианта разведывательно-ударной системы или комплекса с учетом военных, экономических и временных факторов, которые вливают на их создание, содержание и применение, а также сформирована полную структурно-логическая схема предложенного подхода. В свою очередь предложенный методический подход позволяет сформировать основные рекомендации о порядке его применения в штабах, службах
\end{abstract}


Вооруженных Силах Украины при формировании программ и планов развития вооружения и военной техники Вооруженных Сил Украины и Вооруженных Сил Украины в целом.

Ключевые слова: показатель, критерии, боевая готовность, разведывательно-ударная система.

\title{
Recommendations for application of the methodological approach to the military-economic justification of the choice of a rational variant of the reconnaissance-strike system or complex in the programs (plans)
}

\author{
Oleh Semenenko ${ }^{1 \text { A; }}$ Artem Remez ${ }^{2}$ B; Vladimir Musienko 3 C; \\ Ivan Motrunych ${ }^{4}$; ; Andrii Bulhakov ${ }^{5}$; Oleh Tarasov 6 F \\ ${ }^{1}$ Corresponding author: Dr, Senior Research Fellow, Head of Department, e-mail: aosemenenko@ukr.net, ORCID: 0000-0001-6477-3414 \\ ${ }^{2}$ PhD student, e-mail: remez.art.86@gmail.com, ORCID: 0000-0003-4970-1097 \\ 3 e-mail: aosemenenko@ukr.net, ORCID: 0000-0002-4909-6045 \\ ${ }^{4}$ e-mail: aosemenenko@ukr.net, ORCID: 0000-0002-6463-7639 \\ ${ }^{5}$ e-mail: bulggakof@ukr.net, ORCID: 0000-0003-4139-6761 \\ ${ }^{6}$ Candidate of Military Sciences, e-mail: tarasovo@ukr.net

\footnotetext{
${ }^{A}$ Central Research Institute of the Armed Forces of Ukraine, 28, Povitroflotsky, ave, Kyiv, 03049, Ukraine

${ }^{B}$ National Defence University of Ukraine named after Ivan Cherniachovskyi, 28, Povitroflotsky, ave, Kyiv, 03049, Ukraine ${ }^{D}$ General Staff of the Armed Forces of Ukraine, 6, Povitroflotskyi Ave. Kyiv, 03168, Ukraine

F National Aviation University, 1, Lubomyr Husar Ave., Kyiv, 03058, Ukraine
} \\ ${ }^{c}$ Heroes of Kruty Military Institute of Telecommunications and Informatization, 45/1, Moscow, vul., Kyiv, 01011, Ukraine
}

\section{Abstract}

The state of the domestic economy and the level of implementation of modern technologies at the enterprises of the military-industrial complex make it problematic to fulfill all plans for the rearmament of the Armed Forces of Ukraine in a timely manner. Therefore, the most acceptable, both from a military and from an economic point of view, is the approach of situational integration of available forces and assets into target systems in a single information space by integrating reconnaissance, control and destruction assets. A reconnaissance and strike system, built of a multitude of subsystems united by information relations, which function as a whole, on the basis of uniform principles and rules, with agreed basic requirements for their components, which will increase the effectiveness of the combat use of troops due to a synergistic effect. Today, the integration of various forces and assets into target systems creates the preconditions for the existence of several possible variants of these systems, which have different assessments of the effectiveness of their use, the cost indicators of their creation, maintenance and use, as well as different time intervals for bringing them to combat readiness. Therefore, the system of indicators and criteria for evaluating and comparing various options for reconnaissance and strike systems or complexes, as well as existing approaches to justifying the choice of a rational option for these systems or complexes should have an integral criterion for choosing a priority option in the current situation. Therefore, the authors in the article proposed a general structure for constructing a methodological approach to a military-economic justification for the choice of a rational version of a reconnaissance-strike system or complex, taking into account military, economic and temporary factors that contribute to their creation, content and application, and also formed a complete structural and logical scheme of the proposed approach. In turn, the proposed methodological approach makes it possible to formulate basic recommendations on the procedure for its application in the headquarters, services of the Armed Forces of Ukraine in the formation of programs and plans for the development of weapons and military equipment of the Armed Forces of Ukraine and the Armed Forces of Ukraine as a whole.

Keywords: indicator, criteria, combat readiness, reconnaissance and strike system. 


\section{References}

1. Kompleks vooruzhenyia. URL: http://knowledge.su/k/kompleksvooruzheniya.

2. Danyk Yu. H. ta insh. Monitorynh obiektiv v umovakh apriornoi nevyznachenosti dzherel informatsii. Teoriia ta praktyka / avtorskyi kolektyv Yu. A. Bobalo, Yu. H. Danyk, L. O. Komarovia, O. O. Lukianov, V. M. Maksymovych, O. O. Pysarchuk, V. V. Rippenbein, R. T. Smuk, V. S. Stohnii, Yu. B. Storonskyi, B. M. Strykhaliuk. - Drohobych Lviv: Kolo, 2014. 252 s.

3. Rozviduvalno-udarni, rozviduvalno-vohnevi kompleksy (pryntsypy pobudovy $v$ umovakh realizatsii kontseptsii merezhetsentrychnykh viin, otsinka efektyvnosti boiovoho zastosuvannia) : monohrafiia / za zah. red. V. M. Telelyma / V. M. Tarasov, R. I. Tymoshenko, O. M. Zahorka. Kyiv: NUOU, 2015. - $184 \mathrm{~s}$.

4. Zahorka O. M. Do pytannia zastosuvannia rozviduvalno-udarnykh i rozviduvalnovohnevykh kompleksiv

$u$
merezhetsentrychnii viini / O. M. Zahorka, V. O. Kolesnykov, V. V. Koval, I. O. Zahorka // Nauka i tekhnika Povitrianykh Syl Zbroinykh Syl Ukrainy. - 2012. - № 3. - S. 8-13. URL: http://nbuv.gov.ua/UJRN/Nitps_2012_3_5.

5. Khomchak R.B., Semnenko O.M., Bokii V.H., Zvarych A.O., Remez A.V. Teoretychni aspekty prohnozuvannia rezultativ rozvytku Zbroinykh Syl Ukrainy $z$ urakhuvanniam otsinok dostatnosti ekonomichnykh mozhlyvostei derzhavy // Zb. nauk. pr. TsNDI ZS Ukrainy. Kyiv. 2020. № 2 (93). S. 6-24.

6. Razvedbivatelno-udarnыe kompleksы у razvedbivatelnыe systemы ynostrannыkh armyi

URL: http://studbooks.net/1194609/bzhd/razved yvatelno_udarnye_kompleksy_razvedyvatel nye_sistemy_inostranny $h$ _armiy.

7. Semenenko, O., Salkutsan, S., Romanchenko, O., Marko, Y., Dobrovolska, L., \& Remez, A. (2020). Main methodological aspects of assessing the relationship between the defense and economic potential of the state in the framework of forming requirements for its requirements. Journal of Scientific Papers "Social Development and Security", 10(6), 161-177. DOI: 10.33445/sds.2020.10.6.15

8. Kosmos y kharakter sovremennukh voennukh deistvyi. URL: http://kiksssr.ru/Main_Oko.htm.

9. Semenenko O., Vodchyts O., Bulhakov A., Remez A., Remez V. (2021) Methodological approach to justification of decisions on update of samples of weapons and military equipment on the basis of the criteria of economy of economy of performance by them of tasks on purpose // Sciences of Europe, (Praha, Czech Republic), vol 3, № 63, pp. 49-55.

10. Telelym V. M., Muzychenko D. P., Punda Yu. V. Planuvannia syl dlia vykonannia boiovykh zavdan u "hibrydnii viini» // Nauka i oborona №3. 2014. S.30-35.

11. Saiapyn O. V., Tykhanыchev O. V., Chernov N. A. Sozdanye mezhvydovoi razvedblvatelno-porazhaiushchei systemb kak osnovы povыshenyia эffektyvnosty ohnevoho porazhenyia. Voennaia mosl. 2017. №6. S. 32-37.

12. Semenenko O. M., Remez A. V., Romanchenko O. A., Bondarenko O. Ye. Zahalna strukturno-lohichna skhema ta zmist metodyky voienno-ekonomichnoho obgruntuvannia vyboru ratsionalnoho variantu rozviduvalno-udarnoi systemy dlia Zbroinykh Syl Ukrainy / Zb. nauk. pr. Tsentralnoho naukovo-doslidnoho instytutu Zbroinykh Syl Ukrainy. Kyiv: TsNDI ZS Ukrainy, 2020. №4 (95). S. 36-45.

13. The Implementation of Network - Centric Warfare - [Elektronnyi resurs] URL: http://www.iwar.org.uk/ rma /resources/ $\mathrm{ncw} /$ implementation-of-NCW.pdf. 